\title{
Net flux of nutrients across splanchnic tissues in wethers consuming grasses of different sources and physical forms ad libitum*†
}

\author{
BY A. L. GOETSCH ${ }^{1}$, A. R. PATIL ${ }^{2}$, D. L. GALLOWAY ${ }^{2}$, B. KOUAKOU ${ }^{2}$, \\ Z. S. WANG ${ }^{2}$, K. K. PARK ${ }^{2}$ AND J. E. ROSSI ${ }^{2}$ \\ 'Dale Bumpers Small Farm Research Center, Agricultural Research Service, USDA, Booneville, \\ AR 72927-9214, USA \\ ${ }^{2}$ Department of Animal Science, University of Arkansas, Fayetteville, AR 72701, USA
}

(Received 27 December 1995 - Revised 13 June 1996 - Accepted 3 October 1996)

Crossbred sheep ( $n$ 16, 8.5 months of age and 33 (SE 0.9) $\mathrm{kg}$ ) were used in a $21 \mathrm{~d}$ experiment $(2 \times 2$ factorial) to determine effects on net flux of nutrients across the portal-drained viscera (PDV) and liver of ad libitum consumption of bermudagrass (Cynodon dactylon; B) v. ryegrass (Lolium multiflorum)-wheat (Triticum aestivum; RW) hay, coarsely chopped (CC) or finely ground and pelleted (GP). Crude protein concentrations were 86, 81, 113 and $119 \mathrm{~g} / \mathrm{kg}$ and neutral-detergent fibre concentrations were $710,688,654$ and $672 \mathrm{~g} / \mathrm{kg}$ (dry matter basis) for B-CC, B-GP, RW-CC and RW-GP respectively. Digestible energy intake $(6.0,9.6,10.2$ and $13.8 \mathrm{MJ} / \mathrm{d})$ differed $(P<0.01)$ with grass source and form, and digestible $N$ intake values were $4 \cdot 4,7 \cdot 0,8 \cdot 4$ and $14 \cdot 1$ (SEM 0.82) g/d for B-CC, B-GP, RW-CC and RW-GP diets respectively. Consumption of $\mathrm{O}_{2}$ by the PDV (118, 165, 144 and $155 \mathrm{mmol} / \mathrm{h})$ and splanchnic bed $(196,273,247$ and $266 \mathrm{mmol} / \mathrm{h}$ for B-CC, B-GP, RW-CC and RW-GP respectively) was greater $(P=0 \cdot 07)$ for $G P$ than for $C C$. The ratio splanchnic heat energy production : digestible energy intake was greater $(P=0 \cdot 06)$ for $B$ than for $\mathrm{RW}(0 \cdot 374,0 \cdot 300$, 0.278 and 0.219 for B-CC, B-GP, RW-CC and RW-GP respectively). $\alpha$-Amino-N release by the PDV $(P<0.01 ; 11.6,12.8,23.0$ and $18.7 \mathrm{mmol} / \mathrm{h})$ and uptake by the liver $(P=0.07 ; 15.2,6.1,17.0$ and $19.3 \mathrm{mmol} / \mathrm{h}$ for B-CC, B-GP, RW-CC and RW-GP respectively) were greater for RW than for B. Release of $\mathrm{NH}_{3}-\mathrm{N}$ by the PDV was greater $(P=0.02)$ for $\mathrm{CC}$ than for $\mathrm{GP}(12.5,6.2,15.7$ and $8.9 \mathrm{mmol} / \mathrm{h})$, and hepatic urea-N release differed between grass sources $(P=0 \cdot 03)$ and physical forms $(P=0.07 ; 22.6,12 \cdot 7,31.4$ and $24.8 \mathrm{mmol} / \mathrm{h}$ for B-CC, B-GP, RW-CC and RW-GP respectively). In conclusion, decreases in forage particle size elicited by grinding and pelleting did not affect the difference between grass sources in splanchnic tissue heat energy production relative to digestible energy intake.

Forage: Splanchnic metabolism: Sheep

Effects of fine grinding and pelleting forage on ruminant performance are often not explained solely by changes in absorbed nutrients (Berger et al. 1994), implying an improved efficiency of metabolism. The grinding and pelleting of forage decreases eating time per unit of intake, and whole-body energy expenditure is markedly increased during eating (Webster, 1980). Grinding and pelleting also has, in some instances, increased ruminal propionate concentration (Fahey et al. 1993; Berger et al. 1994), which conceivably, with

\footnotetext{
* Published with the approval of the Director of the Arkansas Agricultural Experiment Station, manuscript no. 95145.

$\dagger$ Mention of a trademark or proprietary product in this paper does not constitute a guarantee or warranty of the product by the USDA or the ARS and does not imply its approval to the exclusion of other products that also may be suitable.
} 
constant hepatic glucose release, could lessen hepatic energy use and uptake of amino acids for gluconeogenesis (Seal \& Reynolds, 1993). Grinding and pelleting has not consistently altered microbial protein synthesized per unit of organic matter fermented; therefore, a marked change in the ratio absorbed energy:amino acids is not expected. Whether effects of grinding and pelleting forage on gut metabolism of amino acids parallel those on energy use is unclear. However, an increased potential for amino acid use by peripheral tissues and, hence, possibly decreased hepatic uptake of amino acids, might be facilitated by grinding and pelleting if increased peripheral energy availability allows enhanced protein synthesis.

Lower digestibility of tropical than temperate grass results in lower absorption of both energy and amino acids, although in many instances peripheral availability of energy appears to be relatively more limiting to tissue accretion than that of amino acids (Galyean \& Goetsch, 1993). Because eating time relates directly to dietary cell-wall concentration (Dulphy et al. 1980), it is anticipated that tropical grass diets elicit greater energy use for ingestion than temperate grasses. Unique proportions and arrangements of specific plant tissues in tropical and temperate grasses may contribute to greater gut digesta mass for tropical grass and differences in the nature of digesta (Wilson, 1993). Sun et al. (1994) and Kouakou et al. (1995b) largely attributed differences in gut tissue mass among diets varying in concentrate level or forage quality to gut digesta mass, and direct effects of gut tissue mass on that of the liver, independent of the influence of digestible organic matter intake, were suggested also (Kouakou et al. 1995a,b). Differences between forage sources in gut tissue mass and energy use will result in peripheral tissue energy availability deviating from expectations based solely on intake and digestibility. The extent to which differences between tropical and temperate grasses in splanchnic tissue metabolism and ingestive energy use affect energy $v$. amino acid availability to peripheral tissues is unknown.

It is unclear if physical characteristics of tropical and temperate grasses altered by fine grinding and pelleting elicit differences in splanchnic tissue metabolism. The absence or presence and nature of such interactions may aid in understanding forage characteristics responsible for differences in splanchnic metabolism and, thus, in wholebody metabolism. Therefore, the objectives of our experiment were to determine differences in net flux of $\mathrm{O}_{2}$ and nutrients across the portal-drained viscera (PDV) and liver with ad libitum consumption of tropical $v$. temperate grass, coarsely chopped or finely ground and pelleted.

\section{MATERIALS AND METHODS}

Sixteen crossbred (Suffolk $\times$ Ramboillet-Dorset) wethers (33 (SE 0.9) kg body weight; 8.5 months of age) were surgically fitted with chronic indwelling catheters in a hepatic vein, the portal vein and a mesenteric vein and artery (Ferrell et al. 1992). Catheters were filled with heparinized $(100 \mathrm{U} / \mathrm{ml})$ saline $(0.85 \mathrm{~mol} / \mathrm{l})$ solution at surgery. The sheep began the experiment approximately 5 weeks after surgery, being previously used in a $23 \mathrm{~d}$ experiment (Goetsch et al. 1996) with ad libitum consumption of different mixtures of the same sources of grass hay used in the present experiment. To avert or minimize effects of treatments in the previous experiment on results in the present one, wethers were allocated to treatments for equal distribution relative to previous treatments. This involved subjecting one wether from each of the four previous treatments to each treatment in the present experiment. Sheep were individually maintained in $1.1 \times 1.5 \mathrm{~m}$ elevated pens with 
an expanded metal floor and free access to water. Sheep were cared for in accordance with the guidelines of Consortium (1988).

Diets were prepared from a bermudagrass hay $(\mathrm{B} ;$ Cynodon dactylon; harvested at the vegetative stage of growth) or a ryegrass-wheat hay (RW; composed of Lolium multiflorum (harvested at the late-vegetative to boot stage of growth) and Triticum aestivum (harvested at the post-anthesis to early milk stage)). Diets were offered either coarsely chopped (B$\mathrm{CC}$; RW-CC) or finely ground and pelleted (B-GP; RW-GP) at $1.05-1.10 \mathrm{~g} / \mathrm{g}$ of consumption on the preceding $2-4 \mathrm{~d}$. Grinding was through a $1.6 \mathrm{~mm}$ screen and pellets were formed with a $4.8 \mathrm{~mm}$ die. Temperature during pelleting was slightly greater for $\mathrm{B}$ than for RW $\left(60 v .45^{\circ}\right)$, with hay subjected to steam for approximately $45 \mathrm{~s}$. Equal-sized meals were given to sheep at $14.00,22.00$ and 06.00 hours and at 14.00 hours sheep received $3.5 \mathrm{~g}$ of a mineral mixture containing $200 \mathrm{~g}$ trace minerals $/ \mathrm{kg}$ and $800 \mathrm{~g} \mathrm{salt} / \mathrm{kg}$. The trace mineral mixture contained (mg/g): Zn 120, Mn 100, K 50, Mg 25, Cu 15, I 3, Co 1 and $\mathrm{Se} 0.2$.

The experiment was $21 \mathrm{~d}$ in length. Feed was sampled daily on days 11-21 and combined to form a composite. In addition, ground hay was sampled before pelleting for mean particle size determination. Percentages of time in a $24 \mathrm{~h}$ period spent standing $v$. lying, eating, ruminating or idle (time not spent eating or ruminating) were determined by observation at $15 \mathrm{~min}$ intervals on day 13 . Grab samples of faeces were collected on days 14-17, at $12 \mathrm{~h}$ intervals advancing $3 \mathrm{~h}$ daily. Samples were frozen between collections, dried at $55^{\circ}$, ground to pass a $2 \mathrm{~mm}$ screen and used to form a composite. Rumen fluid was obtained by stomach tube on day 16 at 09.00 hours, strained through cheesecloth, acidified

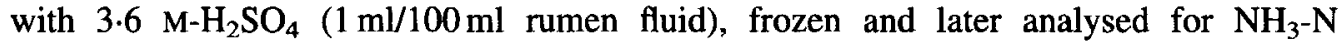
(Broderick \& Kang, 1980).

Metabolism cages were used to house sheep during blood collections, with four sheep sampled daily (one per treatment; chosen randomly within treatment) on days 18-21. Sheep were accustomed to metabolism cages because of prior exposure to these conditions and displayed normal intake and other activities while in cages. A priming dose $(15 \mathrm{ml})$ of $p$-aminohippuric acid $(22.5 \mathrm{~g} / \mathrm{l})$ was given at 07.30 hours into the mesenteric vein catheter, followed by continuous infusion $(0.8 \mathrm{ml} / \mathrm{min})$ until 15.25 hours. The priming dose and infusion were through a $0.2 \mu \mathrm{m}$ sterile filter. Body weight was determined immediately after the last sample was obtained.

Blood was withdrawn at $08.00,09.00,10.00,11.00,12.00,12.00,14.00$ and 15.00 hours with a $10 \mathrm{~min}$ interval between sheep and representing an entire $8 \mathrm{~h}$ feeding interval. The treatment order for sampling differed among days. A blood sample $(1 \mathrm{ml})$ was obtained anaerobically into a heparinized syringe and placed in ice for immediate measurement of packed cell volume and $\mathrm{O}_{2}$ concentration (OSM 2; Radiometer Corporation, Copenhagen, Denmark) as described by Eisemann \& Nienaber (1990). Additionally, a $10 \mathrm{ml}$ sample was taken in a tube with potassium oxalate and $\mathrm{NaF}$ and placed in ice, from which a $1.5 \mathrm{ml}$ portion was diluted with deionized water $(4.5 \mathrm{ml})$ for the same-day analysis of $p$ aminohippuric acid, $\alpha$-amino-N (AAN), urea-N (UN) and $\mathrm{NH}_{3}-\mathrm{N}$, as described by Eisemann \& Nienaber (1990). Concentrations of $p$-aminohippuric acid, AAN, UN, $\mathrm{NH}_{3}-\mathrm{N}$ and packed cell volume were averaged across time for calculation of blood flows and metabolite fluxes. Packed cell volume was used to estimate plasma flows. Remaining blood of the $10 \mathrm{ml}$ sample was used to form a composite across sampling times. Plasma for glucose analysis (Sigma Diagnostics, procedure no. 315; Sigma Chemical Co., St. Louis, $\mathrm{MO}, \mathrm{USA})$ was harvested via centrifugation. Deproteinized blood $\left(\mathrm{Ba}(\mathrm{OH})_{2}\right.$ and $\left.\mathrm{ZnSO}_{4}\right)$ was used for analysis of propionate (Yen et al. 1991), except that iso-caproic acid was added as an internal standard before GC. Deproteinized blood $\left(\mathrm{HClO}_{4}\right.$; Harmon et al. 1991) 
was used to determine the concentration of L-lactate (Gutmann \& Wahlefeld, 1974). Net metabolite fluxes were calculated based on venoarterial concentration differences and whole blood or plasma flows (Burrin et al. 1991).

Faecal composites were dried at $55^{\circ}$ and allowed to air-equilibrate. Hay and faecal samples were ground to pass a $1 \mathrm{~mm}$ screen and analysed for $\mathrm{DM}$, ash, Kjeldahl $\mathrm{N}$, energy (Association of Official Analytical Chemists, 1984), neutral-detergent fibre (Goering \& Van Soest, 1970; without sodium sulphite, decalin or ethoxyethanol) and acid-insoluble ash ( $2 \mathrm{M}-\mathrm{HCl}$; Van Keulen \& Young, 1977). Hay samples were also analysed for aciddetergent fibre (non-sequential), acid-detergent lignin, acid-detergent fibre-N (Goering \& Van Soest, 1970) and $\mathrm{N}$ soluble in $0.15 \mathrm{M}-\mathrm{NaCl}$ (Waldo \& Goering, 1979). Cellulose was estimated as loss in weight on $\mathrm{H}_{2} \mathrm{SO}_{4}$ treatment and hemicellulose as the difference between neutral-detergent- and acid-detergent fibre. The average of feed intake on day 12 through to the day of blood sampling was used to calculate digestibilities, with use of acidinsoluble ash as an internal, inert marker. Hay sampled after grinding but before pelleting was sieved through screen apertures of $4.75,2.36,1.18,0.60,0.30,0.15,0.075$ and $0 \mathrm{~mm}$ to determine mean particle size.

Data were analysed as a completely random design by ANOVA and the general linear models procedure of Statistical Analysis Systems (1990). Treatment allotment and sampling day assignment of wethers were conducted to avoid treatment bias; thus, these factors were not considered statistically. Orthogonal contrasts were used to test effects of grass source (B v. RW), form (CC v. GP) and their interaction. The general linear models procedure was used for most regressions, and the regression procedure of Statistical Analysis Systems (1990) was used to determine partial regression coefficients. Hepatic and splanchnic fluxes were not calculated for one wether because of a non-patent hepatic catheter. Therefore, the number of observations was sixteen for feed intake, digestibility, rumen fluid concentration of $\mathrm{NH}_{3}-\mathrm{N}$, behaviour, metabolite concentrations in arterial and portal blood and PDV net fluxes; fifteen observations were derived for hepatic venous blood concentrations of metabolites and hepatic and splanchnic net fluxes. Differences were considered significant with $P \leq 0 \cdot 10$.

\section{RESULTS AND DISCUSSION}

\section{Forage composition}

Composite samples of feedstuffs were subjected to laboratory analyses; therefore, these data were not statistically analysed. Concentrations of crude protein and fibre fractions were not markedly altered by grinding and pelleting (Table 1). Heat generated in grinding and/or pelleting increased acid-detergent-fibre $\mathrm{N}$ concentration more with $\mathrm{RW}$ than $\mathrm{B}$, although the decline in soluble $\mathrm{N}$ concentration was of similar magnitude for both grass sources. Consequently, a small increase with grinding and pelleting in insoluble available $\mathrm{N}$ occurred for $\mathrm{B}$, but a decrease was noted for RW. Mean particle sizes were 0.45 and $0.54 \mathrm{~mm}$ for B-GP and RW-GP respectively.

\section{Intake, digestibility, rumen ammonia-nitrogen concentration and behaviour}

DM intake was greater $(P<0.01)$ for RW than for B and for ground and pelleted than for coarsely chopped grass, with a slightly greater difference between physical forms than grass sources (Table 2). The effect of grinding and pelleting on DM intake ( 0.57 fractional increase) was greater than noted by Greenhalgh \& Reid (1973; 0.45 fractional increase). Effects of grinding and pelleting on intake have been shown to vary among forages (Berger 
Table 1. Grass hay composition (dry matter basis)

\begin{tabular}{|c|c|c|c|c|}
\hline \multirow[b]{2}{*}{ Constituent } & \multicolumn{2}{|c|}{ Bermudagrass } & \multicolumn{2}{|c|}{ Ryegrass-wheat } \\
\hline & $\begin{array}{l}\text { Coarsely } \\
\text { chopped }\end{array}$ & $\begin{array}{l}\text { Ground and } \\
\text { pelleted }\end{array}$ & $\begin{array}{l}\text { Coarsely } \\
\text { chopped }\end{array}$ & $\begin{array}{l}\text { Ground and } \\
\text { pelleted }\end{array}$ \\
\hline Ash $(\mathrm{g} / \mathrm{kg})$ & 68 & 65 & 80 & 82 \\
\hline Crude protein $(\mathrm{g} / \mathrm{kg})$ & 86 & 81 & 113 & 119 \\
\hline Energy $(\mathrm{MJ} / \mathrm{kg})$ & 16.6 & 16.7 & 16.9 & 17.6 \\
\hline Neutral-detergent fibre $(\mathrm{g} / \mathrm{kg})$ & 710 & 688 & 654 & 672 \\
\hline Acid-detergent fibre $(\mathrm{g} / \mathrm{kg})$ & 326 & 303 & 356 & 342 \\
\hline Acid-detergent lignin $(\mathrm{g} / \mathrm{kg})$ & 61 & 54 & 47 & 44 \\
\hline Cellulose $(\mathrm{g} / \mathrm{kg})$ & 263 & 247 & 307 & 294 \\
\hline Hemicellulose $(\mathrm{g} / \mathrm{kg})$ & 384 & 385 & 298 & 330 \\
\hline Acid-detergent fibre- $\mathrm{N}(\mathrm{g} / \mathrm{kg}$ total $\mathrm{N}$ ) & 115 & 158 & 57 & 150 \\
\hline Soluble $\mathrm{N}(\mathrm{g} / \mathrm{kg}$ total $\mathrm{N})$ & 653 & 580 & 571 & 535 \\
\hline Insoluble available $\mathrm{N}(\mathrm{g} / \mathrm{kg}$ total $\mathrm{N}$ ) & 232 & 262 & 382 & 315 \\
\hline
\end{tabular}

Table 2. Feed intake and digestion by wethers consuming bermudagrass or ryegrass-wheat hay coarsely chopped or ground and pelleted*

(Mean values and pooled standard error for four sheep per dietary group)

\begin{tabular}{|c|c|c|c|c|c|c|}
\hline \multirow[b]{2}{*}{ Variable } & \multicolumn{2}{|c|}{ Bermudagrass } & \multicolumn{2}{|c|}{ Ryegrass-wheat } & \multirow[b]{2}{*}{ SEM $\dagger$} & \multirow{2}{*}{$\begin{array}{c}\text { Statistical } \\
\text { significance } \\
\text { of effect of: }\end{array}$} \\
\hline & $\begin{array}{l}\text { Coarsely } \\
\text { chopped }\end{array}$ & $\begin{array}{l}\text { Ground and } \\
\text { pelleted }\end{array}$ & $\begin{array}{l}\text { Coarsely } \\
\text { chopped }\end{array}$ & $\begin{array}{l}\text { Ground and } \\
\text { pelleted }\end{array}$ & & \\
\hline Dry matter intake $(\mathrm{g} / \mathrm{d})$ & 665 & 1123 & 923 & 1370 & $79 \cdot 0$ & G, F \\
\hline \multicolumn{7}{|l|}{ Organic matter } \\
\hline Intake $(g / d)$ & 620 & 1050 & 849 & 1257 & 73.1 & G, F \\
\hline \multicolumn{7}{|l|}{ Digestion } \\
\hline g/kg & 561 & 530 & 668 & 584 & 33.9 & G \\
\hline $\mathrm{g} / \mathrm{d}$ & 343 & 556 & 573 & 736 & $51 \cdot 3$ & G, F \\
\hline \multicolumn{7}{|l|}{ Energy } \\
\hline Intake (MJ/d) & $11 \cdot 1$ & 18.7 & $15 \cdot 6$ & $24 \cdot 1$ & 1.35 & G, F \\
\hline \multicolumn{7}{|l|}{ Digestion } \\
\hline $\mathbf{k J} / \mathbf{M J}$ & 551 & 516 & 650 & 571 & 3.34 & G \\
\hline MJ & 6.0 & 9.6 & 10.2 & 13.8 & 0.91 & $\mathrm{G}, \mathrm{F}$ \\
\hline \multicolumn{7}{|l|}{ Nitrogen } \\
\hline Intake $(\mathrm{g} / \mathrm{d})$ & 9.1 & 14.5 & 16.7 & $26 \cdot 1$ & 1.33 & G, F \\
\hline \multicolumn{7}{|l|}{ Digestion } \\
\hline $\mathrm{g} / \mathrm{kg}$ & 495 & 486 & 496 & 540 & 3.99 & \\
\hline $\mathrm{g} / \mathrm{d}$ & 4.4 & 7.0 & 8.4 & $14 \cdot 1$ & 0.82 & $G, F, i$ \\
\hline \multicolumn{7}{|l|}{ Neutral-detergent fibre } \\
\hline Intake $(\mathrm{g} / \mathrm{d})$ & 477 & 773 & 604 & 921 & 53.5 & $\mathrm{G}, \mathrm{F}$ \\
\hline \multicolumn{7}{|l|}{ Digestion } \\
\hline $\mathrm{g} / \mathrm{kg}$ & 533 & 471 & 694 & 577 & 3.53 & G, F \\
\hline $\mathrm{g} / \mathrm{d}$ & 247 & 364 & 423 & 533 & 37.2 & G, F \\
\hline
\end{tabular}

* For details of diets and procedures, see Table 1 and pp. 770-772.

† Error df 12.

$\mp \mathrm{G}$, grass source (bermudagrass $v$. ryegrass-wheat; $P<0.05$ ); F, grass form (coarsely chopped $v$. ground and pelleted; $P<0.05)$; i, interaction between grass source and form $(P<0.10)$. 
et al. 1994). For example, Coleman et al. (1978) observed slightly greater effects of grinding and pelleting on intake of paragrass (Brachiaria mutica) than of St Augustinegrass (Stenotaphrum secundatum) and on intake of grasses harvested after 8 weeks of regrowth than after 4 weeks. However, in the present experiment grinding and pelleting had a comparable effect on intake of both grass sources.

Organic matter digestibility was greater $(P=0.03)$ for $\mathrm{RW}$ than for $\mathrm{B}$ and tended $(P=0.11)$ to be decreased by grinding and pelleting (Table 2$)$. Consequently, digestible energy intake (DEI) was considerably greater for RW than for $\mathrm{B}(P<0.01)$ and for ground and pelleted than for coarsely chopped grass $(P<0.01)$. Total tract $\mathrm{N}$ digestibility was similar among treatments. An interaction $(P=0.08)$ between grass source and form occurred, with digestible $N$ intake being increased by grinding and pelleting to a slightly greater extent with RW than $B$.

Neutral-detergent fibre digestibility was lower for B than for RW $(P<0.01)$ and for ground and pelleted than for coarsely chopped grass $(P=0.03)$, although no statistical interaction occurred (Table 2). Tropical grass cell walls are less digestible than cell walls of temperate grasses (Minson, 1990); however, grinding and pelleting usually decreases ruminal fibre digestibility because of shortened ruminal digesta residence time (Fahey et al. 1993).

Ruminal $\mathrm{NH}_{3}-\mathrm{N}$ concentration was not significantly affected by grinding and pelleting but was greater $(P=0.09)$ for RW than for B (Table 3$)$, perhaps in large part because of the difference in forage $\mathrm{N}$ concentration. However, the difference in ruminal $\mathrm{NH}_{3}-\mathrm{N}$ concentration was less than expected based simply on forage $\mathrm{N}$ concentration. Because a statistical interaction between grass source and physical form was not detected, perhaps synchrony of fermentation was not markedly changed by grinding and pelleting.

Proportions of a $24 \mathrm{~h}$ period spent standing and lying were not affected by diet (Table 3). Grinding and pelleting slightly increased eating time with $B$, but with $R W$ a decrease occurred (interaction; $P=0.03)$. Grinding and pelleting markedly decreased $(P<0.01)$ time spent ruminating, which largely accounted for a substantial increase $(P<0.01)$ in idle time.

Table 3. Rumen fluid ammonia-nitrogen concentration and behaviour in wethers consuming bermudagrass or ryegrass-wheat coarsely chopped or ground and pelleted*

(Mean values and pooled standard error for four sheep per dietary group)

\begin{tabular}{|c|c|c|c|c|c|c|}
\hline \multirow[b]{2}{*}{ Variable } & \multicolumn{2}{|c|}{ Bermudagrass } & \multicolumn{2}{|c|}{ Ryegrass-wheat } & \multirow[b]{2}{*}{ SEM† } & \multirow{2}{*}{$\begin{array}{c}\text { Statistical } \\
\text { significance } \\
\text { of effect of: }\end{array}$} \\
\hline & $\begin{array}{l}\text { Coarsely } \\
\text { chopped }\end{array}$ & $\begin{array}{l}\text { Ground and } \\
\text { pelleted }\end{array}$ & $\begin{array}{l}\text { Coarsely } \\
\text { chopped }\end{array}$ & $\begin{array}{l}\text { Ground and } \\
\text { pelleted }\end{array}$ & & \\
\hline $\begin{array}{l}\text { Ammonia-N (mmol/l) } \\
\text { Behaviour (fraction of } 24 \mathrm{~h} \text { ) }\end{array}$ & 3.7 & 3.7 & $6 \cdot 0$ & 4.2 & 0.75 & $\mathrm{~g}$ \\
\hline Standing & 0.294 & 0.357 & 0.365 & 0.378 & 0.0349 & \\
\hline Lying & 0.706 & 0.643 & 0.635 & 0.622 & 0.0349 & \\
\hline Eating & 0.174 & 0.198 & 0.227 & 0.161 & 0.0173 & I \\
\hline Ruminating & 0.424 & 0.323 & 0.383 & 0.281 & 0.0316 & $\mathrm{~F}$ \\
\hline Idle & 0.401 & 0.479 & 0.391 & 0.557 & 0.0268 & $\mathrm{~F}$ \\
\hline
\end{tabular}

* For details of diets and procedures, see Table 1 and pp. 770-772.

$\uparrow$ Error df 12 .

$\ddagger \mathrm{g}$, grass source (bermudagrass $v$. ryegrass-wheat; $P<0.10$ ); $\mathrm{F}$, grass form (coarsely chopped $v$. ground and pelleted; $P<0.05) ; \mathrm{I}$, interaction between grass source and form $(P<0.05)$. 


\section{Blood flow and oxygen}

Portal and hepatic venous and hepatic arterial blood flows were not affected by diet (Table 4). $\mathrm{O}_{2}$ consumption by the PDV was increased $(P=0.07)$ by grinding and pelleting but was similar for $\mathrm{B}$ and RW diets; splanchnic bed $\mathrm{O}_{2}$ consumption was greater $(P=0.07)$ for ground and pelleted than for coarsely chopped grass; and hepatic $\mathrm{O}_{2}$ consumption tended $(P=0.11)$ to be greater for ground and pelleted than for coarsely chopped grass. Expressed on a daily basis and assuming $0.46 \mathrm{MJ}$ heat energy produced per mol $\mathrm{O}_{2}$ consumed (McLean, 1972), as a proportion of DEI, PDV and splanchnic heat energy production were greater for $\mathrm{B}$ than for $\mathrm{RW}$, and a similar trend $(P=0.13)$ in hepatic heat energy production occurred. The significance level of grass form effects for PDV, hepatic and splanchnic heat energy production as a proportion of DEI was $0 \cdot 14$.

That grass source and form were not statistically interactive in the ratio splanchnic bed heat energy production:DEI suggests that physical characteristics of forage affected by grinding and pelleting were not responsible for the higher ratio for $\mathrm{B}$ than for $\mathrm{RW}$ diets. Influences of factors other than DEI, or physiological workload, on splanchnic tissue heat production relative to DEI may be evidenced by a higher correlation between splanchnic tissue $\mathrm{O}_{2}$ consumption and DM intake $(r 0.63 ; P=0.01)$ than between splanchnic tissue $\mathrm{O}_{2}$ consumption and DEI $(r 0.53 ; P=0.04)$. However, results of this experiment do not allow identification of characteristics of $B$ or physiological changes its consumption elicited that were responsible for greater splanchnic heat production:DEI compared with consumption of RW. Nonetheless, two factors that may have contributed to this difference involve gut digesta mass and eating time.

The 'girder' structure of tropical grass fragments, entailing plant tissues with protruding and jagged edges, leads to entanglement in the rumen digesta mat, which contributes to slow rumen digesta exit and high digesta mass (Wilson, 1993). In accordance, reticulo-rumen digesta mass has been shown to be greater for tropical than for temperate grass diets (Sun et al. 1994; Kouakou et al. 1995a,b). The proportion and integrity of arrangements of specific plant tissues presumably were not affected by grinding and pelleting in the present experiment (Fahey et al. 1993; Berger et al. 1994). Thus, grinding and pelleting may not have altered differences between grass sources in digesta mass. Digesta mass appears to have an impact on PDV energy consumption (Reynolds et al. 1991; Sun et al. 1994; Kouakou et al. 1995b) via expenditures for gut muscular contractions and in epithelial cell metabolic activity, with effects on the latter factor being much greater (Webster, 1980). In addition, effects of the nature of digesta in the gut, apart from its mass, on gut tissue energy use are plausible. Results of Rompala et al. $(1988,1990)$ provide some support for this possibility, as effects of dietary addition of inert bulky substances with constant DEI altered gastrointestinal tract tissue characteristics.

The second factor presumably contributing to the lower splanchnic tissue energy use:DEI ratio for $\mathrm{B}$ than for $\mathrm{RW}$ is the longer period of time spent eating relative to DEI. The relationship between eating time and PDV heat production encompasses muscular activities involved in prehension, mastication, swallowing and gut contractions and gut epithelial cell metabolism, although again, the largest contributor is metabolism by the gut epithelium (Kelly et al. 1989; Seal \& Reynolds, 1993). How eating time may have interacted with differences in digesta characteristics and the relative importances of each factor in influencing PDV energy use in the present experiment are unclear. Other factors not measured that may have been involved in the different ratio for the grass sources include potential differences in microbial production and gastrointestinal tract concentrations and absorption of volatile fatty acids. 
Table 4. Whole-blood flow and oxygen and $\alpha$-amino, urea and ammonia nitrogen measures in sheep consuming bermudagrass or ryegrass-wheat coarsely chopped or ground and pelleted*

(Mean values and pooled standard error for four sheep per dietary group)

\begin{tabular}{|c|c|c|c|c|c|c|}
\hline \multirow[b]{2}{*}{ Variable } & \multicolumn{2}{|c|}{ Bermudagrass } & \multicolumn{2}{|c|}{ Ryegrass-wheat } & \multirow[b]{2}{*}{ SEM $\dagger$} & \multirow{2}{*}{$\begin{array}{l}\text { Statistical } \\
\text { significance } \\
\text { of effect of: } \ddagger\end{array}$} \\
\hline & $\begin{array}{l}\text { Coarsely } \\
\text { chopped }\end{array}$ & $\begin{array}{l}\text { Ground and } \\
\text { pelleted }\end{array}$ & $\begin{array}{l}\text { Coarsely } \\
\text { chopped }\end{array}$ & $\begin{array}{l}\text { Ground and } \\
\text { pelleted }\end{array}$ & & \\
\hline \multicolumn{7}{|l|}{ Blood flow (litres/h) } \\
\hline Portal vein & 112 & 121 & 103 & 110 & $10 \cdot 6$ & \\
\hline Hepatic vein & 127 & 147 & 124 & 131 & $12 \cdot 0$ & \\
\hline Hepatic artery & 15 & 21 & 21 & 21 & $2 \cdot 7$ & \\
\hline \multicolumn{7}{|c|}{ Oxygen } \\
\hline \multicolumn{7}{|c|}{ Whole-blood concentration (mmol/l) } \\
\hline Portal vein & 2.87 & 2.73 & 2.99 & 2.95 & 0.229 & \\
\hline Hepatic vein & 2.38 & $2.24 \|$ & 2.41 & 2.32 & 0.244 & \\
\hline Artery & 3.93 & 4.09 & 4.40 & 4.37 & 0.255 & \\
\hline \multicolumn{7}{|l|}{ Consumption $(\mathrm{mmol} / \mathrm{h})$} \\
\hline Portal-drained viscera & 118 & 165 & 144 & 155 & $14 \cdot 2$ & f \\
\hline Hepatic & 78 & 106 & 103 & 111 & 10.6 & \\
\hline Splanchnic & 196 & 273 & 247 & 266 & 24.0 & f \\
\hline \multicolumn{7}{|c|}{ Heat energy production : digestible energy intake§ } \\
\hline Portal-drained viscera & 0.225 & $0 \cdot 188$ & $0 \cdot 163$ & 0.128 & 0.0227 & G \\
\hline Hepatic & 0.149 & 0.116 & 0.115 & 0.091 & 0.0180 & \\
\hline Splanchnic & 0.374 & 0.300 & 0.278 & 0.219 & 0.0412 & g \\
\hline \multicolumn{7}{|c|}{$\alpha$-Amino-N } \\
\hline \multicolumn{7}{|c|}{ Whole-blood concentration ( $\mathrm{mmol} / \mathrm{l})$} \\
\hline Portal vein & 4.27 & 4.91 & 4.73 & 5.62 & 0.296 & $\mathrm{~g}, \mathrm{~F}$ \\
\hline Hepatic vein & $4 \cdot 14$ & $5.02 \|$ & 4.55 & 5.44 & 0.303 & $F$ \\
\hline Artery & $4 \cdot 16$ & 4.80 & 4.49 & 5.36 & 0.286 & $\mathrm{~F}$ \\
\hline \multicolumn{7}{|l|}{ Net flux $(\mathrm{mmol} / \mathrm{h})$} \\
\hline Portal-drained viscera & 11.6 & $12 \cdot 8$ & $23 \cdot 0$ & 28.7 & 3.74 & $\mathrm{G}$ \\
\hline Hepatic & $-15 \cdot 2$ & $-6 \cdot 1 \|$ & -17.0 & $-19 \cdot 3$ & 3.81 & $\mathrm{~g}$ \\
\hline Splanchnic & $-3 \cdot 5$ & $8 \cdot 3 \|$ & 6.0 & 9.4 & $5 \cdot 38$ & \\
\hline \multicolumn{7}{|c|}{ Urea-N } \\
\hline \multicolumn{7}{|c|}{ Whole-blood concentration $(\mathrm{mmol} / \mathrm{l})$} \\
\hline Portal vein & 4.02 & 2.23 & $3 \cdot 30$ & 2.99 & 0.447 & $\mathbf{F}$ \\
\hline Hepatic vein & 4.21 & $2 \cdot 24 \|$ & 3.60 & 3.21 & 0.500 & $\mathrm{~F}$ \\
\hline Artery & $4 \cdot 17$ & $2 \cdot 35$ & 3.53 & $3 \cdot 13$ & 0.468 & $\mathrm{~F}$ \\
\hline \multicolumn{7}{|l|}{ Net flux $(\mathrm{mmol} / \mathrm{h})$} \\
\hline Portal-drained viscera & $-17 \cdot 2$ & -14.7 & $-24 \cdot 5$ & -15.0 & $4 \cdot 11$ & \\
\hline Hepatic & 22.6 & $12 \cdot 7 \|$ & 31.4 & 24.8 & 4.05 & $\mathrm{G}, \mathrm{f}$ \\
\hline Splanchnic & $5 \cdot 3$ & $-0.5 \|$ & $7 \cdot 0$ & 9.8 & 2.44 & $\mathrm{G}$ \\
\hline \multicolumn{7}{|c|}{ Ammonia-N } \\
\hline \multicolumn{7}{|c|}{ Whole-blood concentration (mmol/l) } \\
\hline Portal vein & 0.500 & 0.531 & 0.588 & 0.584 & 0.0595 & \\
\hline Hepatic vein & 0.366 & $0.462 \|$ & 0.405 & 0.487 & 0.0709 & \\
\hline Artery & 0.388 & 0.479 & 0.433 & 0.502 & 0.0715 & \\
\hline \multicolumn{7}{|l|}{ Net flux $(\mathrm{mmol} / \mathrm{h})$} \\
\hline Portal-drained viscera & 12.5 & 6.2 & 15.7 & 8.9 & $2 \cdot 34$ & $F$ \\
\hline Hepatic & -15.2 & $-8.8 \|$ & $-19 \cdot 3$ & -10.9 & 2.42 & $\mathbf{F}$ \\
\hline Splanchnic & -2.7 & $-2 \cdot 6 \|$ & $-3 \cdot 6$ & $-2 \cdot 0$ & $1 \cdot 32$ & \\
\hline
\end{tabular}

* For details of diets and procedures, see Table 1 and pp. 770-772.

$\dagger$ Error df for portal venous and arterial blood concentrations and portal-drained viscera net fluxes 12; error df for hepatic venous blood concentrations and hepatic and splanchnic net fluxes 11 .

$\ddagger \mathrm{G}$ and $\mathrm{g}$, grass source (bermudagrass $v$. ryegrass-wheat; $P<0.05$ and $P<0.10$ respectively); $\mathrm{F}$ and $\mathrm{f}$, grass form (coarsely chopped $v$. ground and pelleted; $P<0.05$ and $P<0.10$ respectively).

$\S$ Assuming $0.46 \mathrm{MJ}$ heat energy per mol $\mathrm{O}_{2}$ consumed.

$\| n 3$. 
Differences between grass sources in splanchnic tissue heat energy production relative to DEI were similar to results of previous experiments with ad libitum intake where differences were found to be due to factors other than DEI (Patil et al. 1995, 1996; Goetsch et al. 1996). Conversely, DEI as an index of physiological workload appears to be a relatively more important determinant of splanchnic tissue energy use with limited or restricted intake (Johnson et al. 1990). Perhaps metabolic activity more closely aligns with, and is markedly influenced by, physiological workload at different levels of restricted feed intake; whereas, with ad libitum intake of various diets, the degree of excess in metabolic machinery maintained relative to energy and nutrients absorbed decreases with increasing DEI and is relatively susceptible to influences of conditions apart from DEI.

\section{Nitrogenous compounds}

Release of AAN by the PDV was greater $(P<0.01)$ for RW than for B (Table 4$)$, which probably may be explained by greater microbial protein synthesis with greater DEI and digestible $\mathrm{N}$ intake for RW than for $\mathrm{B}$. Possibly as a result of the difference between grass sources in PDV AAN release, hepatic uptake of AAN was greater $(P=0.07)$ for $\mathrm{RW}$, implying at least a slight excess of amino acids available to peripheral tissues relative to protein requirement. This is supported by greater $(P=0.03)$ splanchnic UN release for RW than for $B$, suggesting that the quantity of amino acids available to peripheral tissues coincided more closely with the rate of protein synthesis supported by available energy from $B$ than RW diets.

Grass form did not influence AAN net fluxes (Table 4), suggesting that microbial protein synthesis was not enhanced by grinding and pelleting or that intestinal availability of feed protein escaping ruminal digestion was depressed by grinding and pelleting. Concentrations of acid-detergent fibre- $\mathrm{N}$, soluble $\mathrm{N}$ and insoluble available $\mathrm{N}$ in feedstuffs imply that grinding and pelleting did not appreciably change rumen outflow of intestinally available feed protein, and perhaps elicited a slight decrease. In support, PDV release and hepatic uptake of $\mathrm{NH}_{3}-\mathrm{N}$ were lower $(P=0.02$ and $P=0.01$ respectively) for ground and pelleted than for coarsely chopped grass, indicating that rumen protein degradation was lessened by grinding and pelleting. Thus, grinding and pelleting did not appear to increase microbial protein synthesis. In accordance, grinding and pelleting has inconsistently altered microbial protein synthesis and growth efficiency (Fahey et al. 1993; Berger et al. 1994). However, other factors that could have been involved in these results include effects of grass form on the quantity of amino acids released by the PDV in peptides, accompanied by an underestimation of amino acid release with AAN as the index, and change in PDV metabolism of amino acids.

UN uptake by the PDV (Table 4) was not influenced by either grass source or form, which may relate to concurrent changes in DEI and digestible $\mathrm{N}$ intake. Hepatic UN release was greater for RW than for $\mathrm{B}(P=0.03)$ and for coarsely chopped than for ground and pelleted grass $(P=0.07)$. Hepatic uptakes of both AAN and $\mathrm{NH}_{3}-\mathrm{N}$ were correlated with UN hepatic release $(r 0.71$ and $r 0.81$ respectively; $P<0.01)$. Even though not all $\mathrm{NH}_{3}-\mathrm{N}$ and AAN taken up by the liver gives rise to $\mathrm{UN}$, a regression of hepatic $\mathrm{UN}$ release on $\mathrm{NH}_{3}-\mathrm{N}$ and AAN uptakes accounted for $74 \%$ of variation, of which 64 and $36 \%$ was attributable to uptakes of $\mathrm{NH}_{3}-\mathrm{N}$ and AAN respectively. As a proportion of hepatic UN release, hepatic uptake of AAN was similar among treatments $(0.65$ (SE 0.078)), whereas hepatic $\mathrm{NH}_{3}-\mathrm{N}$ uptake was greater $(P=0.09)$ for $\mathrm{B}$ than for RW $(0.83,0.70,0.61$ and 0.45 for B-CC, B-GP, RW-CC and RW-GP respectively; SEM 0.123). Hence, $\mathrm{NH}_{3}-\mathrm{N}$ may have contributed relatively more $\mathrm{N}$ to urea being released by the liver with $\mathrm{B}$ than $\mathrm{RW}$ diets. 
This may relate both to the lower digestibility of B than of RW, which limited potential for rumen microbial incorporation of $\mathrm{NH}_{3}-\mathrm{N}$, and to presumably lower microbial protein production and subsequent intestinal absorption of amino acids with $\mathrm{B}$. These results depict the importance of adequate rumen fermentable organic matter for capture of a high proportion of $\mathrm{N}$ in forage protein by rumen micro-organisms and impact of the rumen available $\mathrm{N}$ :organic matter ratio on $\mathrm{N}$ ultimately excreted as urea.

\section{Glucose, propionate and lactate}

Glucose net fluxes were not influenced by dietary treatment (Table 5). Therefore, it appears that PDV metabolism of glucose did not change with DEI as it varied with grass source and form. This is in contrast with relationships between DEI or metabolizable energy intake

Table 5. Glucose, propionate and lactate measures in wethers consuming bermudagrass or ryegrass-wheat coarsely chopped or ground and pelleted*

(Mean values and pooled standard errors for four sheep per dietary group)

\begin{tabular}{|c|c|c|c|c|c|c|}
\hline \multirow[b]{2}{*}{ Variable } & \multicolumn{2}{|c|}{ Bermudagrass } & \multicolumn{2}{|c|}{ Ryegrass-wheat } & \multirow[b]{2}{*}{ SEM $\dagger$} & \multirow{2}{*}{$\begin{array}{c}\text { Statistical } \\
\text { significance } \\
\text { of effect of: } \neq\end{array}$} \\
\hline & $\begin{array}{l}\text { Coarsely } \\
\text { chopped }\end{array}$ & $\begin{array}{l}\text { Ground and } \\
\text { pelleted }\end{array}$ & $\begin{array}{l}\text { Coarsely } \\
\text { chopped }\end{array}$ & $\begin{array}{l}\text { Ground and } \\
\text { pelleted }\end{array}$ & & \\
\hline \multicolumn{7}{|c|}{ Glucose } \\
\hline \multicolumn{7}{|c|}{ Plasma concentration (mmol/1) } \\
\hline Portal vein & $2 \cdot 60$ & 2.86 & 3.05 & 3.40 & 0.160 & $\mathrm{G}, \mathrm{f}$ \\
\hline Hepatic vein & 2.92 & $3 \cdot 11 \S$ & 3.40 & $3 \cdot 70$ & 0.172 & $\mathrm{G}$ \\
\hline Artery & 2.71 & 2.89 & $3 \cdot 14$ & $3 \cdot 51$ & $0 \cdot 156$ & $G, f$ \\
\hline \multicolumn{7}{|l|}{ Net flux $(\mathrm{mmol} / \mathrm{h})$} \\
\hline Portal-drained viscera & $-10 \cdot 3$ & -2.7 & $-8 \cdot 3$ & -9.3 & 5.82 & \\
\hline Hepatic & $30 \cdot 4$ & $19.2 \S$ & $32 \cdot 1$ & 27.7 & 4.87 & \\
\hline Splanchnic & $20 \cdot 1$ & $16.0 \$$ & 23.8 & 18.4 & 5.04 & \\
\hline \multicolumn{7}{|l|}{ Propionate } \\
\hline \multicolumn{7}{|c|}{ Whole-blood concentration $(\mathrm{mmol} / \mathrm{l})$} \\
\hline Portal vein & 0.186 & $0 \cdot 164$ & $0 \cdot 243$ & 0.229 & 0.0426 & \\
\hline Hepatic vein & 0.049 & $0.034 \S$ & 0.056 & $0-038$ & 0.0110 & \\
\hline Artery & 0.037 & $0.027^{\circ}$ & 0.044 & 0.028 & 0.0062 & f \\
\hline \multicolumn{7}{|l|}{ Net flux $(\mathrm{mmol} / \mathrm{h})$} \\
\hline Portal-drained viscera & $16 \cdot 5$ & $17 \cdot 6$ & 21.6 & 23.2 & 5.63 & \\
\hline Hepatic & $-15 \cdot 1$ & $-17.8 \S$ & $-20 \cdot 0$ & -22.2 & 6.25 & \\
\hline Splanchnic & 1.4 & $1.2 \S$ & 1.6 & 1.0 & 1.26 & \\
\hline \multicolumn{7}{|c|}{ Lactate } \\
\hline \multicolumn{7}{|c|}{ Whole-blood concentration $(\mathrm{mmol} / \mathrm{l})$} \\
\hline Portal vein & 0.45 & 0.65 & 0.56 & 0.65 & 0.075 & f \\
\hline Hepatic vein & 0.33 & $0.46 \S$ & 0.40 & 0.40 & 0.051 & \\
\hline Artery & $0 \cdot 34$ & 0.48 & 0.45 & 0.42 & $0-059$ & \\
\hline \multicolumn{7}{|l|}{ Net fux $(\mathrm{mmol} / \mathrm{h})$} \\
\hline Portal-drained viscera & $11 \cdot 2$ & 19.7 & 11.2 & $25 \cdot 3$ & 5.45 & $\mathrm{f}$ \\
\hline Hepatic & $-12 \cdot 0$ & $-22.6 \S$ & -17.4 & $-28 \cdot 7$ & 5.73 & $\mathrm{f}$ \\
\hline Splanchnic & -0.8 & -8.08 & $-6 \cdot 2$ & $-3 \cdot 3$ & 3.61 & \\
\hline
\end{tabular}

* For details of diets and procedures, see Table 1 and pp. 770-772.

$\dagger$ Error df for portal venous and arterial blood concentrations and portal-drained viscera net fluxes 12 ; error df for hepatic venous blood concentrations and hepatic and splanchnic net fluxes 11 .

$\ddagger \mathrm{G}$, grass source (bermudagrass $v$. ryegrass-wheat; $P<0.05$ ); $f$, grass form (coarsely chopped $v$. ground and pelleted; $\S n 3$.

$$
P<0 \cdot 10) \text {. }
$$


and whole-body glucose turnover or hepatic production noted in other studies with limited intake (Brockman, 1993). This discrepancy may reflect a relatively small change in demand by the whole-body for glucose with differences in ad libitum intake of moderateto low-quality forages compared with different levels of restricted intake. In accordance with no treatment effect on hepatic glucose release, propionate release by the PDV and hepatic uptake were not influenced by treatment. Lactate release by the PDV $(P=0.06)$ and uptake by the liver $(P=0.08)$ were greater for ground and pelleted than for coarsely chopped grass (Table 5). Reasons for these differences are not apparent. Lactate released by the PDV can arise from microbial production, which would not be expected to be appreciable with forage diets, and from epithelial cell metabolism of propionate and glucose. Because glucose uptake by the PDV was similar among diets, it is doubtful that change in its metabolism was responsible.

\section{Summary}

Results of this experiment indicate that splanchnic tissue energy metabolism relative to DEI differs between tropical and temperate grasses but is comparably enhanced by grinding and pelleting with similar increases in DEI. Possible factors responsible for such differences include effects of diet characteristics on gut digesta mass and thus on gut tissue mass, and energy used in heat-generating processes associated with eating. The absence of a statistical interaction between grass source and physical form suggests that physical characteristics of the forage influenced by grinding and pelleting (presumably primarily decreased particle size without marked change in the proportion or integrity of arrangements of specific plant tissues) were not responsible for differences between grass sources in splanchnic tissue energy consumption relative to DEI.

The authors would like to express appreciation to the NRI Competitive Grants Program/ USDA (Award No. 92-37208-8185) and Arkansas Science and Technology Authority (Award No. 94-B-02) for partial financial support.

\section{REFERENCES}

Association of Official Analytical Chemists (1984). Official Methods of Analysis, 14th ed. Washington, DC: AOAC.

Berger, L. L., Fahey, G. C., Jr, Bourquin, L. D. \& Titgemeyer, E. C. (1994). Modification of forage quality after harvest. In Forage Quality, Evaluation, and Utilization, pp. 922-966 [G. C. Fahey, Jr, editor]. Madison, WI: American Society of Agronomy, Crop Science Society of America, Soil Science Society of America.

Brockman, R. P. (1993). Glucose and short-chain fatty acid metabolism. In Quantitative Aspects of Ruminant Digestion and Metabolism, pp. 249-266 [J. M. Forbes and J. France, editors]. Wallingford: CAB International.

Broderick, G. A. \& Kang, J. H. (1980). Automated simultaneous determination of ammonia and total amino acids in ruminal fluid and in vitro media. Journal of Dairy Science 63, 64-75.

Burrin, D. G., Ferrell, C. L., Eisemann, J. H. \& Britton, R. A. (1991). Level of nutrition and splanchnic metabolite flux in young lambs. Joumal of Animal Science 69, 1082-1091.

Coleman, S. W., Neri-Flores, O., Allen, R. J., Jr \& Moore, J. E. (1978). Effect of pelleting and of forage maturity on quality of two sub-tropical forage grasses. Journal of Animal Science 46, 1103-1112.

Consortium (1988). Guide for the Care and Use of Agricultural Animals in Agricultural Research and Teaching. Champaign, IL: Editorial Production Services, Association Headquarters.

Dulphy, J. P., Remond, B. \& Theriez, M. (1980). Ingestive behaviour and related activities in ruminants. In Digestive Physiology and Metabolism in Ruminants, pp. 103-122 [Y. Ruckebusch and P. Thivend, editors]. Westport, CT: AVI Publishing Co.

Eisemann, J. H. \& Nienaber, J. A. (1990). Tissue and whole-body oxygen uptake in fed and fasted steers. British Journal of Nutrition 54, 399-411.

Fahey, G. C. Jr, Bourquin, L. D., Titgemeyer, E. C. \& Atwell, D. G. (1993). Postharvest treatment of fibrous feedstuffs to improve their nutritive value. In Forage Cell Wall Structure and Digestibility, pp. 715-766 
[H. G. Jung, D. R. Buxton, R. D. Hatfield and J. Ralph, editors]. Madison, WI: American Society of Agronomy, Crop Science Society of America, Soil Science Society of America.

Ferrell, C. L., Britton, R. A. \& Freetly, H. C. (1992). Chronic catheterization of hepatic and portal veins of sheep. In Handbook of Methods for Study of Reproductive Physiology in Domestic Animals, Section VIII A \& F [P. Dziuk and M. Wheeler, editors]. Urbana, IL: University of Illinois.

Galyean, M. L. \& Goetsch, A. L. (1993). Utilization of forage fiber by ruminants. In Forage Cell Wall Structure and Digestibility, pp. 33-72 [H. G. Jung, D. R. Buxton, R. D. Hatfield and J. Ralph, editors]. Madison, WI: American Society of Agronomy, Crop Science Society of America, Soil Science Society of America.

Goering, H. K. \& Van Soest, P. J. (1970). Forage Fiber Analyses. Apparatus, Reagents, Procedures and Some Applications. Agricultural Handbook no. 379. Washington, DC: ARS, USDA.

Goetsch, A. L., Patil, A. R., Galloway, D. L., Sr, Wang, Z. S., Kouakou, B. \& Rossi, J. E. (1996). Oxygen consumption by splanchnic tissues in wethers consuming ad libitum different proportions of bermudagrass and ryegrass-wheat. Archives of Animal Nutrition 50 (In the Press).

Greenhalgh, J. F. D. \& Reid, G. W. (1973). Long- and short-term effects on intake of pelleting a roughage for sheep. Animal Production 19, 77-86.

Gutmann, I. \& Wahlefeld, A. W. (1974). L(+)Lactate determination with lactate dehydrogenase and NAD. In Methods of Enzymatic Analysis, vol. 3, pp. 1464-1468 [H. U. Bergmeyer, editor]. New York: Academic Press.

Harmon, D. L., Gross, K. L., Kreikemeier, K. K., Coffey, K. P., Avery, T. B. \& Klindt, J. (1991). Effects of feeding endophyte-infected fescue hay on portal and hepatic nutrient flux in steers. Journal of Animal Science 69, 1223-1231.

Johnson, D. E., Johnson, K. A. \& Baldwin, R. L. (1990). Changes in liver and gastrointestinal tract energy demands in response to physiological workload in ruminants. Journal of Nutrition 120, 649-655.

Kelly, J. M., Vaage, A. S., McBride, B. W. \& Milligan, L. P. (1989). Oxygen consumption and the energy costs of $\mathrm{Na}^{+}, \mathrm{K}^{+}$-ATPase in rumen epithelial papillae from Hereford steers. Journal of Dairy Science 72, Suppl. 1, 560.

Kouakou, B., Goetsch, A. L., Patil, A. R., Galloway, D. L. \& Park, K. K. (1995a), Effects of forage source and grain level on performance and visceral organ mass of growing wethers. Journal of Animal Science 73, Suppl. $1,32$.

Kouakou, B., Goetsch, A. L., Patil, A. R., Galloway, D. L., Sr, Park, K. K. \& West, C. P. (1995b). Effects of grass source and maturity on performance and visceral organ mass in growing wethers. Journal of Animal Science 73, Suppl. 1, 261.

McLean, J. A. (1972). On the calculation of heat production from open-circuit calorimetric measurements. British Journal of Nutrition 27, 597-600.

Minson, D. J. (1990). Forage in Ruminant Nutrition, pp. 9-149. San Diego, CA: Academic Press.

Patil, A. R., Goetsch, A. L., Park, K. K., Kouakou, B., Galloway, D. L. \& Johnson, Z. B. (1996). Influences of grass source and legume level on net flux of nutrients across splanchnic tissues in sheep. Small Ruminant Research 22, 111-122.

Patil, A. R., Goetsch, A. L., Park, K. K., Kouakou, B., Galloway, D. L., Sr, West, C. P. \& Johnson, Z. B. (1995). Net flux of nutrients across splanchnic tissues in sheep fed tropical vs. temperate grass hay of moderate or low qualities. Livestock Production Science 43, 49-61.

Reynolds, C. K., Tyrrell, H. F. \& Reynolds, P. J. (1991). Effects of diet forage-to-concentrate ratio and intake on energy metabolism in growing beef heifers: whole body energy metabolism and nitrogen balance and visceral heat production. Journal of Nutrition 121, 994-1003.

Rompala, R. E., Hoagland, T. A. \& Meister, J. A. (1988). Effect of dietary bulk on organ mass, fasting heat production and metabolism of the small and large intestines in sheep. Journal of Nutrition 118, 1553-1557.

Rompala, R. E., Hoagland, T. A. \& Meister, J. A. (1990). Modifications in growth and morphology of ovine jejunal and ruminal epithelia as affected by inert dietary substances. Journal of Animal Science 68, 25302535.

Seal, C. J. \& Reynolds, C. K. (1993). Nutritional implications of gastrointestinal and liver metabolism in ruminants. Nutrition Research Reviews 6, 185-208.

Statistical Analysis Systems (1990). SAS/STAT User's Guide, version 6, 4th ed., vol. 2. Cary, NC: SAS Institute, Inc.

Sun, W., Goetsch, A. L., Forster, L. A. Jr, Galloway, D. L. Sr \& Lewis, P. K. Jr (1994). Forage and splanchnic tissue mass in growing lambs: effects of dietary forage levels and source on splanchnic tissue mass in growing lambs. British Journal of Nutrition 71, 141-151.

Van Keulen, J. \& Young, B. A. (1977). Evaluation of acid-insoluble ash as a natural marker in ruminant digestibility studies. Joumal of Animal Science 44, 282-287.

Waldo, D. R. \& Goering, H. K. (1979). Insolubility of proteins in ruminant feeds by four methods. Journal of Animal Science 49, 1560-1568.

Webster, A. J. F. (1980). Energy costs of digestion and metabolism in the gut. In Digestive Physiology and Metabolism in Ruminants, pp. 469-484 [Y. Ruckebusch and P. Thivend, editors]. Westport, CT: AVI Publishing Co. 
Wilson, J. R. (1993). Organization of forage plant tissues. In Forage Cell Wall Structure and Digestibility, pp. 1-32 [H. G. Jung, D. R. Buxton, R. D. Hatfield and J. Ralph, editors]. Madison, WI: American Society of Agronomy, Crop Science Society of America, Soil Science Society of America.

Yen, J. T., Nienaber, J. A., Hill, D. A. \& Pond, W. G. (1991). Potential contribution of absorbed volatile fatty acids to whole-animal energy requirement in conscious swine. Journal of Animal Science 69, 2001-2012. 